\section{Estatísticas sanitárias e interdependência social na Primeira República}

\section{Sanitary statistics and social interdependence during the First Republic}

\footnotetext{
Alexandre de Paiva Rio Camargo ${ }^{i}$

Professor, Instituto Universitário de Pesquisas do Rio de Janeiro/ Universidade Cândido Mendes. Rio de Janeiro - RJ - Brasil

orcid.org/0000-0001-5720-7369

alexandre.camargo.2009@gmail.com
}

CAMARGO, Alexandre de Paiva Rio. Estatísticas sanitárias e interdependência social na Primeira República. História, Ciências, Saúde - Manguinhos, Rio de Janeiro, v.28, n.4, out.-dez. 2021, p.10071035.

Resumo

$\mathrm{O}$ artigo analisa o lugar das tecnologias de quantificação na rede formada em torno do combate às doenças, da revolução pastoriana até o movimento sanitarista dos anos 1920. Investiga o papel da demografia sanitária na imposição do modelo pastoriano entre os médicos, seguido da monumentalização estatística das reformas junto a diferentes atores sociais. A teoria do ator-rede de Bruno Latour e os trabalhos de Michel Foucault sobre a governamentalidade são usados para problematizar o conjunto documental formado pelo censo de 1906, artigos e boletins demográficos publicados na imprensa médica, anuários estatísticos e relatórios ministeriais.

Palavras-chave: estatísticas sanitárias; revolução pastoriana; questão nacional; movimento sanitarista.

\section{Abstract}

This article analyzes the place of quantification technologies in the network formed to fight diseases, from the Pasteurian revolution to the sanitation movement of the 1920s. It investigates the role of sanitary demography in the imposition of the Pasteurian model among physicians, followed by the statistical monumentalization of the reforms for different social actors. Bruno Latour's actornetwork theory and Michel Foucault's works on governmentality are used to problematize a set of documents consisting of the 1906 census, demographic articles and bulletins published in the medical press, statistical yearbooks and ministerial reports.

Keywords: sanitary statistics; Pasteurian revolution; national problem; sanitary movement. 
U ma das grandes lacunas nos estudos sociais e históricos da saúde diz respeito aos modos de raciocinar, categorizar, medir e comparar com números e estatísticas as ciências biomédicas e as políticas de saúde. Como as formas de classificação mediante contagem foram empregadas para impor diagnósticos e definições de situação de médicos e higienistas junto a públicos diversos e heterogêneos, inicialmente refratários às necessidades e aos interesses de uma elite de especialistas? Como os dispositivos de quantificação, como tabelas, gráficos, mapas e diagramas, ajudaram a resolver controvérsias e formar consensos sobre enunciados científicos? Como a produção e a circulação das estatísticas sanitárias pôde iluminar aspectos importantes do desenvolvimento da profissão médica e da construção da doença como um problema público? Inspirando-nos na sociologia da quantificação (Desrosières, 2008; Diaz-Bone, Didier, 2016; Camargo, Daniel, 2021), tentaremos realizar uma primeira aproximação dessa ordem de questões.

O presente artigo investiga o papel da quantificação na centralização da autoridade sanitária, entre a revolução pastoriana, nos anos 1890, e a eclosão do movimento sanitarista, no final dos anos 1910. Cumpre-nos examinar o papel da demografia sanitária na imposição do modelo pastoriano entre os médicos, assim como avaliar a monumentalização estatística da reforma liderada por Oswaldo Cruz junto a diferentes atores sociais. Assumimos a hipótese de que o processo de implantação da medicina experimental no país ampliou não apenas a produção como também a capacidade de significação das estatísticas sanitárias, ao transformá-las em tecnologia de tradução de interesses da nova geração de médicos bacteriologistas.

Um debate em especial merece ser revisitado à luz da nossa discussão: como a epistemologia democrática das doenças, ignorando as divisões de classe e a estadualização da saúde, vai costurar a interdependência social a partir do movimento de saneamento dos principais centros urbanos? Embora a Constituição de 1891 estabelecesse que cada estado deveria cuidar de si, em matéria de higiene, a transmissibilidade da doença, segundo Gilberto Hochman (2012, p.42), "foi sendo percebida como um problema nacional, não contido na moldura constitucional. O recurso ao Governo Central, mediante acordos de cooperação entre a União e os estados, seria uma alternativa tanto para a regulação da interdependência - territorialidade - e para o enfrentamento dos males públicos quanto para impedir a ação dos caronas e os efeitos dos ineptos - coercitividade".

Como não era possível estabelecer uma fronteira sanitária entre estados vizinhos, a dinâmica da migração interna tendia a reintroduzir continuamente epidemias que os elevados gastos com a infraestrutura de saúde, assumidos por estados mais desenvolvidos como São Paulo, haviam conseguido mitigar ou controlar. Para aquele autor, a consciência da interdependência sanitária teria se originado da preocupação com a forma eficaz de gerir males coletivos. Uma das consequências foi a percepção de que os ricos não estariam protegidos sem assistência sanitária básica aos destituídos, o que foi confirmado pela extrema letalidade da gripe espanhola de 1919 entre as elites e pelo impacto simbólico de sua vítima mais ilustre, o presidente eleito Rodrigues Alves.

Do mesmo modo, a quantificação da realidade também depende de equivalências mínimas entre indivíduos e entre os corpos. Em determinadas formações sociais, comparar dessemelhantes afastados por estatutos de origem e nascimento é algo não só indesejável, 
como impensável, talvez até mesmo uma heresia ou um crime de impiedade. Senhores e escravos, nobres e plebeus, homens e mulheres têm muito mais a separá-los, por natureza e função, do que a agregá-los. Afinal, a "descoberta" da população, de que nos fala Michel Foucault (2009), depende de "convenções de equivalência" entre pessoas, muito mais difíceis de serem construídas onde a personalidade comum não é vista como algo mais significativo que as diferenças de posição entre os grupos sociais. Segundo Theodore Porter (1986, p.25-26), governos como o do Antigo Regime não visualizavam pessoas autônomas, mas membros de estados e ordens, que formavam uma sociedade demasiadamente diferenciada para que um censo pudesse dizer muito sobre o que realmente importava. Uma expansão no escopo da investigação quantitativa dependeria de uma transformação profunda na concepção de seu objeto.

Um espaço de medida comum permite comparar o que permanece incomparável em uma sociedade estamental ou escravista, marcada pela contínua reafirmação das distâncias que separam os indivíduos desde seu nascimento, rigidamente classificados em virtude de sua natureza e sua função na sociedade. Para que a população de um território nacional se torne comparável entre si é necessária uma equivalência anterior que funda distinções posteriores - de ocupação, de renda, de gênero etc. É precisamente essa comparabilidade universal que constitui a população e que equaliza os mais diferentes corpos diante dos fenômenos vitais - de ricos e pobres, de brancos e negros - a nova realidade que vai emergir com a interdependência sanitária construída ao longo da Primeira República (Camargo, 2016).

Sendo assim, este artigo é dedicado a analisar como a construção de equivalências entre os corpos, inicialmente tecida pela epistemologia democrática da doença, permitiu ampliar os usos das estatísticas sanitárias, no movimento que alinhou diferentes interesses em torno da perspectiva sanitarista e da definição da situação produzida a partir do laboratório pastoriano.

Para tanto, nossa exposição se divide em dois momentos: o primeiro pode ser situado aproximadamente entre o início da República, marcado pelas ondas epidêmicas dos anos 1890, e a conclusão, por fim vitoriosa, da reforma sanitária do Distrito Federal, em 1906, mesmo ano de realização do censo do Rio de Janeiro, que, como veremos, foi concebido como um instrumento cognitivo de consolidação daquela reforma. Caracteriza-se por uma estratégia belicosa que acentuava a necessidade de combate, eliminação e erradicação das doenças e, dessa forma, permanecia indiferente à hostilidade e à desconfiança generalizada da população contra as iniciativas do Estado. Sua operacionalização, nesse primeiro instante, seria garantida pela tradução bem-sucedida entre os interesses dos médicos sanitaristas e os das elites oligárquicas e políticas.

O segundo momento é geralmente localizado na eclosão do movimento sanitarista em bases nacionais, que seguiu a mobilização cívica da conjuntura de guerra e a comoção despertada pela publicação dos relatórios da expedição de Artur Neiva e Belisário Pena pelo interior do país, em 1916. O trabalho pioneiro nesse sentido é o de Luiz Antonio de Castro Santos (1985), o primeiro a analisar o movimento sanitarista como desencadeador de uma ideologia nacionalista, sedimentando uma linha de investigação posteriormente retomada pelos estudos de Gilberto Hochman (2012) e Nísia Trindade Lima (1999), com quem dialogamos aqui. 
Por um lado, concordamos com esses autores quanto ao entendimento de que esse segundo intervalo foi decisivo na construção da questão nacional e da interdependência social. Procuramos, inclusive, oferecer subsídios a esse recorte, uma vez que nossa análise da configuração do discurso estatístico aponta na mesma direção, redefinindo a apresentação visual dos dados no censo de 1920 e no Anuário estatístico brasileiro. Por outro lado, recorremos às reflexões sobre a governamentalidade, de Michel Foucault (2008, 2009), e à teoria do ator-rede, de Bruno Latour (1988), para apontar outro enfoque sobre a população, que aparece já nos anos imediatamente posteriores à reforma sanitária na capital federal, entre 1906 e 1914, quando o novo foco dos médicos sobre doenças crônicas, como a tuberculose, e as condições de moradia dos pobres e operários alçou ao primeiro plano a questão da conduta e da ambiência de vida da população, a ser produzida como sujeito saudável. Isso implicava recrutá-la como aliado na rede pastoriana, tornando-a proativa na administração de hábitos higiênicos, sem o que não seria possível controlar determinadas moléstias que ganhariam visibilidade, caso da mencionada tuberculose. Tal deslocamento transparece na hierarquia de moléstias privilegiadas pelos sanitaristas a cada tempo, assim como no discurso quantitativo que monitora o seu desempenho. Nessa chave, formulamos a hipótese de que a projeção da perspectiva médico-sanitarista da sociedade como problema-síntese da nação, a partir de 1916, constitui um deslocamento interno da própria rede pastoriana, em seu campo visual de problematização dos sujeitos doentes e dos espaços de doença.

\section{Da estatística médica à demografia sanitária}

Antes da reorganização institucional da medicina e da higiene, nos anos 1880, o cálculo estatístico era predominantemente constituído por estimativas indiretas ou derivado dos registros hospitalares, com o fim de avaliar a frequência de incidências infecciosas e a eficácia dos tratamentos e das técnicas terapêuticas. Não havia uma agência especializada em organizar os eventos vitais de forma sistemática, cabendo aos dirigentes da Junta Central de Higiene (1851-1886) e outros médicos interessados na evolução das epidemias o trabalho de compilar as estatísticas hospitalares e realizar estimativas sobre a salubridade da Corte. ${ }^{1}$

Embora dispusessem da reserva legal do exercício do ofício, e das sanções que a acompanhavam, os médicos não conseguiriam impor sua definição legítima de medicina sem superar os dissensos constantes em seus periódicos e espaços institucionais, em grande parte decorrentes da multicausalidade e dos múltiplos objetos de combate, característicos do higienismo e do modelo climático-telúrico. O debate sobre a etiologia de certas doenças, como a febre amarela, é exemplar a esse respeito, opondo contagionistas e infeccionistas, as duas grandes tradições do higienismo (Benchimol, 2000, p.265-292).

Em tal quadro, cada médico formulava suas receitas e tinha opiniões firmes, dogmáticas, contra as do concorrente. As estatísticas elaboradas nos hospitais de isolamento ao fim de cada epidemia, às vezes confrontando distintas enfermarias, eram, em geral, empregadas para anular a pretensa superioridade de tal ou qual composição terapêutica, das diferentes linhas que disputavam a hegemonia, dando lugar a outra face da ausência de consenso: o ceticismo terapêutico (Benchimol, 1999, p.35). Por sua própria natureza, a estatística médica 
permanecia subordinada à experiência da clínica. O hospital era a escala observacional a partir da qual os higienistas visualizavam a população.

Dito de outro modo, as estatísticas sobre os eventos vitais eram privadas, no sentido de que eram produzidas por indivíduos particulares, sendo os registros hospitalares complementados com projeções e cálculos indiretos sobre a população. Em geral, eram ocasiões em que o recurso aos dados apenas atestava a tese que se queria defender, antecipando-se os argumentos em contrário. Convém notar, ainda, que a classificação dos óbitos por doenças não era padronizada, o que somente ocorreria com o modelo proposto por Jacques Bertillon, em 1893, e rapidamente adotado por diversos países, inclusive o Brasil.

A reforma do ensino, regulamentada pela Lei Leôncio de Carvalho, em 1879, e aprofundada em 1884, com a mudança dos estatutos da Faculdade de Medicina do Rio de Janeiro, consagrou uma nova representação sobre os fundamentos do saber médico, expressa pela orientação da medicina experimental, que poria fim às dissensões crônicas entre os esculápios, características das décadas anteriores. A introdução de disciplinas como a patologia, a fisiologia, a toxicologia e a epidemiologia, todas a demandar conhecimentos estatísticos mais sólidos, resultou na construção de uma imagem mais pragmática da ciência, no estabelecimento de um programa de pesquisa orientado para o estudo das nosologias e terapêuticas nacionais, e na adoção do ensino prático e livre, por meio da criação de novas cadeiras de clínica especiais e, particularmente, da incorporação do laboratório de higiene. Esse conjunto de medidas subordinou o ensino à pesquisa e tornou a faculdade um espaço de renovação do saber médico; de difusão das teorias parasitológicas das doenças; de combate ao exercício ilegal da medicina e de luta pela implantação da legislação sanitária (Ferreira, Fonseca, Edler, 2001, p.74-75).

A partir da faculdade e sua articulação com associações e institutos de pesquisa internacionais, especialmente os de orientação pastoriana, firmou-se um novo perfil profissional. Ao lado do higienista, que procura prevenir e combater as doenças e epidemias com base em uma pluralidade de causas cósmicas e históricas; ao lado do clínico, cuja prática se relaciona à cura dos doentes, correlacionando descrição de sintomas e interpretação de processos fisiológicos, ambos fundados na observação direta; emerge a figura do médico pastoriano, que se dedica à identificação da causa microbiana, à especificidade etiológica da doença e a sua eventual imunização (Benchimol, 1999, p.14).

A nova organização institucional refletiu-se no periodismo médico. Se, até os anos 1880, a maioria absoluta dos artigos versava sobre "medicina cirúrgica" e "interna", a partir daí as atenções se voltam para o saneamento, as epidemias e a higiene mental como temas fundamentais de uma agenda de saúde pública. A importância da estatística nessa transformação pode ser dimensionada pela criação do cargo de médico demografista, em 1886; pela lei que garantia aos médicos a exclusividade do atestado de óbito - base da estatística de mortalidade por doenças; e, a partir de 1894, pela edição dos boletins quinzenais de demografia sanitária.

Vale frisar que tais iniciativas não apontavam para um movimento contínuo de centralização da higiene, uma vez que os serviços de higiene seriam transferidos aos estados pela Constituição de 1891, cabendo-lhes providenciar os recursos para sua administração. À União, ficavam reservados o controle sanitário dos portos do país, o controle sobre 
o exercício da medicina, a higiene defensiva da capital federal, a competência sobre as pesquisas bacteriológicas em laboratório e a produção das estatísticas demográfico-sanitárias.

A organização da estatística vital e sua subordinação às necessidades do laboratório bacteriológico seriam delineadas com a criação do Instituto Sanitário Federal, por decreto de 12 de janeiro de 1894. Voltado para o estudo da natureza, etiologia, tratamento e profilaxia das moléstias transmissíveis, com destaque para a parasitologia médica, o instituto reunia quatro seções: os hospitais de isolamento, os desinfectórios, o serviço de estatística demográfico-sanitária e o laboratório para estudos bacteriológicos e análises químicas e terapêuticas (Benchimol, 1999, p.254).

Por intermédio de seu laboratório, o instituto tinha por finalidade "o estudo da natureza, etiologia, tratamento e profilaxia das moléstias infectocontagiosas, e das epizootias, bem como quaisquer pesquisas bacteriológicas que interessem à saúde pública" (Brasil, 1895). Cabia-lhe, ainda, a organização das estatísticas demográfico-sanitárias, a produção de um código farmacêutico para ser observado nas repartições federais e a "execução, mediante ordem do governo, de providências de higiene defensiva, em épocas anormais, contra a invasão de moléstias na capital federal" (Brasil, 1895). Seu quadro de pessoal compreendia o diretor-geral, um vice-diretor, um secretário, um arquivista e bibliotecário, três amanuenses, um chefe de laboratório, quatro auxiliares técnicos, um demografista, um ajudante de demografista, um cartógrafo, dois auxiliares de demografia, quatro farmacêuticos, um porteiro e um contínuo.

Reforma idêntica se verificou em São Paulo, onde o serviço sanitário foi reorganizado por lei de setembro de 1893, passando a contar com uma seção de estatística demográficosanitária, anexa ao bacteriológico e ao laboratório de análises químicas. A seção de estatísticas demográfico-sanitárias ficaria marcada pela publicação dos anuários demográficos. A partir de 1894, seriam conhecidos e publicados os dados de registro civil relativos aos nascimentos, casamentos e óbitos, de maneira a dimensionar suas flutuações e inconsistências (Alves, 1999, p.60). Estava posto o modelo institucional, mesmo que o laboratório ainda fosse bastante frágil e precisasse se mostrar eficaz no diagnóstico das doenças e no controle das epidemias, em um meio formado por uma maioria de adeptos do modelo climático-telúrico.

\section{A visualização em série dos fenômenos vitais}

Em Les microbes: guerre et paix, Bruno Latour mostrou como a grande inovação do laboratório pastoriano foi permitir que os micróbios se desenvolvessem sozinhos, isolandoos do ambiente e de outros seres vivos. Esse fato permitiu ao laboratório mover-se para uma infinidade de lugares distantes, fazendo com que as pessoas leigas vissem o mesmo que o bacteriologista, em suas condições ideais de observação. Superava-se, assim, a grande fraqueza dos higienistas, cujo raio de ação recaía sobre tudo o que contivesse a presença humana - o ar, a luz, o calor, a água, o solo -, o que os prendia a uma concepção de humano demasiadamente estreita, que levava a definir sua ciência de forma coextensiva à realidade.

Nessa passagem, a estatística muda de forma e de função. Antes, cabia-lhe visualizar a "espontaneidade mórbida" e o "caráter errático" das doenças, como "ciência aplicada à análise dos fenômenos intangíveis" (Latour, 1988, p.21). Nessa condição, os números 
dificilmente serviam à estabilização dos fatos biomédicos, uma vez que não contribuíam para a afirmação de linhas de raciocínio convergentes. Agora, ao contrário, a estatística, ao lado do microscópio, iria se tornar a tecnologia de visualização por excelência, permitindo correlacionar fenômenos até então independentes e não acessíveis à empiria, como o declínio da mortalidade e a eficácia da vacina. Ao fim de poucos anos, a transferência da vacina produzida no laboratório seria registrada pelas estatísticas como a causa da erradicação da doença (Latour, 1983, p.152).

Mudança semelhante se observa ao longo dos anos 1890 no país. As epidemias oneravam pesadamente as oligarquias e a expansão do Estado. As doenças do gado; as endemias que fechavam os portos à navegação; a falta de uma rede eficiente de estradas, portos e ferrovias; a peste nos portos do Rio e Santos; a malária dizimando trabalhadores que abriam estradas; enfim, toda a paralisia econômica concorria para ampliar a visibilidade política da insalubridade nos centros urbanos e dos efeitos do desacordo entre os médicos. A incapacidade de os médicos "decidirem, intramuros e interpares, quem havia desatado o nó górdio da saúde pública brasileira, levou, inclusive, à proposição, no Congresso e na imprensa, de tribunais onde a questão pudesse ser dirimida" (Benchimol, 2000, p.272-273).

A epidemia de cólera de 1894-1895, no vale do Paraíba paulista, coração da economia cafeeira, é apontada pela historiografia como o episódio inaugural das lutas protagonizadas pelos bacteriologistas, na tentativa de impor sua especialidade como pedra de toque do diagnóstico e das ações de prevenção e neutralização das doenças (Benchimol, 1999; Cukierman, 2007). Foram os boletins demográficos, elaborados por Bulhões Carvalho como médico demografista do Instituto Sanitário Federal e publicados n’O Brasil Médico, que mostraram a exata medida da incidência de moléstias contagiosas, sublinhando a urgência política de resolução do problema.

Em um ano sem grandes surtos epidêmicos no Rio de Janeiro, como o de 1895, por exemplo, em primeiro lugar no índice de mortalidade constava a tuberculose, responsável por $15 \%$ das mortes no Distrito Federal. Seguiam-se, em ordem de grandeza, os casos de febre amarela, varíola, malária, cólera, beribéri, febre tifoide, sarampo, coqueluche, peste, lepra e escarlatina, que, juntos, totalizavam 43\% das mortes registradas na cidade (O Brasil Médico, 15 fev. 1896, p.62). De 1868 a 1914, a tuberculose fez 11.666 vítimas, o que transformava o Rio de Janeiro na cidade de maior incidência em escala mundial (O Brasil Médico citado em Schwarcz, 1993, p.225). Todavia, apesar de sua letalidade mais elevada, a tuberculose não era o foco das atenções, por razões que ficarão mais claras à frente. A mortalidade decorrente dessa doença só era realçada quando se tratava de exaltar a calamidade dos surtos epidêmicos de febre amarela, quando o número de óbitos provocados por ela suplantava o da tuberculose.

A série de boletins quinzenais, iniciada em abril de 1893, desnudava a extrema insalubridade nacional, evidenciando um padrão demográfico bastante alarmante: a taxa de mortalidade superava de muito a de natalidade na capital federal, mesmo nos períodos em que as doenças grassavam apenas endemicamente. Assim, por exemplo, na primeira quinzena de março de 1894, 1.957 pessoas vieram a óbito, enquanto 624 nascimentos foram registrados, diferença três vezes maior em favor da mortalidade (O Brasil Médico, 1 abr. 1894, p.103). Mesmo nos meses fora da estação calmosa - a longa temporada de calor 
e chuvas entre novembro e abril, propícia às epidemias -, era comum os óbitos somarem quase o dobro dos nascimentos. É o caso de setembro de 1895, que contou com 32,64 óbitos contra 23,27 nascimentos, ambos por mil habitantes (O Brasil Médico, 29 set. 1895, p.315). Dificilmente a natalidade superava a mortalidade e a mortinatalidade. Um exemplo é o mês de junho de 1896, quando se chegou ao coeficiente de 20,79 óbitos e de 22,11 nascimentos por mil habitantes (O Brasil Médico, 22 jul. 1896, p.251).

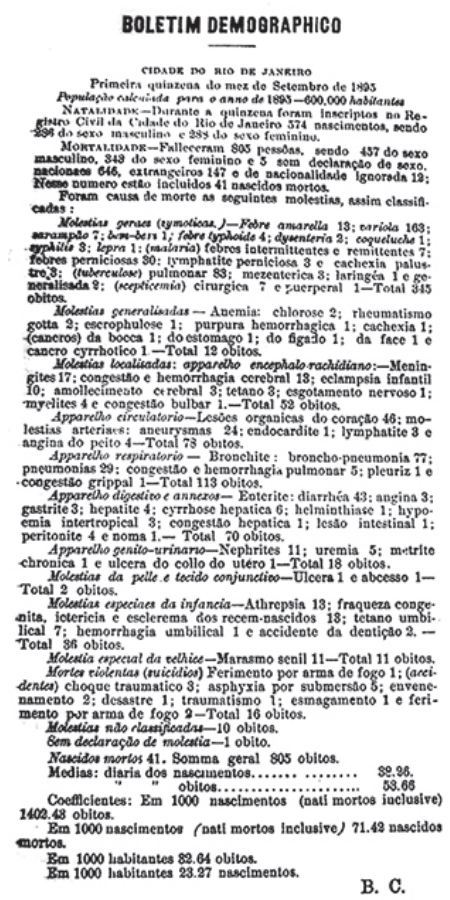

Figura 1: Boletim Demográfico, setembro de 1895 (O Brasil Médico, 29 set. 1895, p.315)

Ao mesmo tempo que a objetivação estatística tornava muito mais sensível a incapacidade dos médicos de responder aos desafios impostos pela epidemiologia, abria novas possibilidades nos procedimentos de prova e argumentação próprios ao debate médico-higienista. O impacto dos boletins nas controvérsias sobre as epidemias passou pela normalização das categorias de causa mortis e sua adesão ao julgamento profissional dos médicos e bacteriologistas, propiciada pela recém-criada nomenclatura internacional de doenças, elaborada em 1893, por Jacques Bertillon.

Levados pela perspectiva analítica de seus produtores, os médicos demografistas, os dados oficiais serão crescentemente apropriados, a partir de 1895, com foco na evolução dos índices de mortalidade e sua distribuição geográfica pelos bairros e distritos da cidade, corroborando as visões dos alinhados com a perspectiva pastoriana de identificação e combate à causa única. As estatísticas sanitárias permitiriam acessar o movimento urbano, modelizando a capital federal em zonas sanitárias, de acordo com a incidência dos focos epidêmicos. Quer dizer que, pela primeira vez, se constituiu um observatório social na escala da cidade, uma tecnologia de visualização completamente diversa da estatística 
hospitalar, que consistia na agregação de registros administrativos, e apenas daqueles que deram entrada na rede assistencial. O campo visual da saúde saía do interior dos espaços fechados para o campo das modulações abertas dos fluxos populacionais.

Uma das consequências imediatas foi a mudança no estatuto da prova numérica, levando à descredibilização das estatísticas privadas, quando estas não estivessem em conformidade com os dados de boletins e anuários demográficos. Um caso sintomático a esse respeito foi a invalidação da vacina de Domingos Freire contra a febre amarela. Gozando da autorização do imperador Pedro II para produzir e aplicar sua vacina, Freire procurava justificar sua eficácia confrontando as mortes causadas pela epidemia e as vidas que julgava ter salvado pela vacinação. Era preciso demonstrar que o universo dos vacinados coincidia com o de vítimas fatais da febre amarela para se inferir que, caso não fossem vacinadas, engrossariam o total de óbitos computados na cidade (Benchimol, 1999, p.103). O fato de essa correlação jamais ter sido adequadamente comprovada por Freire e de ele se basear na sua "experiência" pessoal de médico e observador para atestar a equivalência entre os universos comparados revela que não era a natureza privada das suas estatísticas o principal alvo dos críticos, mas a não especificação das raças dos vacinados e a subestimação de outros fatores que poderiam conferir imunidade natural à doença.

Esse quadro mudaria ao longo dos anos 1890. Uma comissão da Academia Nacional de Medicina, reunida em dezembro de 1898 , decidiu proibir a vacinação, uma vez que não se poderia dar crédito a uma vacina que não fosse preparada com o verdadeiro micro-organismo da febre amarela, expondo os inoculados aos perigos da infecção e contribuindo para manter as portas da cidade abertas a epidemias. Às estatísticas de Freire, que supostamente comprovavam sua ação preservadora, a comissão contrapôs os diagramas dos últimos boletins demográficos da Diretoria-geral de Saúde Pública, mostrando o crescimento da mortalidade por essa doença no período em que foram mais intensas as vacinações (Benchimol, 1999, p.373).

Já não era mais possível recorrer a estimativas populacionais, projeções ou cálculos indiretos que estivessem em desacordo com as estatísticas públicas, como ainda ocorria nas décadas de 1870 e 1880 (Camargo, 2016, 2018). Ao contrário, a validade da prova numérica formulada por médicos e particulares dependeria de sua conformidade com o novo campo visual aberto pelas estatísticas sanitárias. Embora os boletins e os anuários não servissem de subsídios factuais determinantes para as ações sanitárias do final do século XIX e início do século XX, serviam como registro dos efeitos dessas campanhas e como prova de sua eficácia, indicando que a quantificação, enfim, começava a se tornar uma empresa coletiva.

\section{A prova estatística do diagnóstico e da profilaxia}

A construção da credibilidade dos números fica mais evidente quando examinamos o papel ativo dos "médicos demografistas" e das estatísticas sanitárias na formulação do diagnóstico pastoriano e na tradução de interesses entre diferentes grupos sociais. Políticos, imprensa, comerciantes e cafeicultores desconfiavam das provas laboratoriais que atestavam o diagnóstico de epidemias letais, como cólera e febre amarela, valendose da opinião de higienistas ou do conhecimento do clínico, baseado unicamente nos 
sintomas dos doentes que atendia e em sua experiência pessoal. Tentavam, assim, contornar as medidas extenuantes e paralisantes de quarentena, isolamento e desinfecção, que os pastorianos julgavam proscritas, em sua insistência de combate à causa única. As estatísticas de mortalidade por doenças e sua distribuição geográfica pelos focos epidêmicos viriam a confirmar o diagnóstico e a eficiência profilática, exercendo um papel decisivo a cada nova epidemia, inclusive no meio da classe médica, pois as resistências iam diminuindo, enquanto aumentava a confiança na autoridade sanitária.

O Serviço Sanitário paulista, a exemplo de seu congênere federal, teve diversos diagnósticos contestados por parcela significativa da classe médica do estado. Os médicos simplesmente não aceitavam os resultados apresentados. Em 1893, recusaram o diagnóstico de cólera entre os doentes da hospedaria de imigrantes, insistindo na disenteria. O dilema só foi resolvido com o envio de amostras ao Instituto de Medicina Tropical de Hamburgo, que confirmou aquele diagnóstico (Almeida, Dantes, 2001, p.142). Algo similar ocorreria em 1897, quando o órgão alertou que a ocorrência das chamadas "febres paulistas" eram, na verdade, manifestações de febre tifoide. Novamente, o questionamento do diagnóstico só seria resolvido pelo recurso à autoridade internacional. Nesse caso, o envio de amostras ao bacteriologista que havia descoberto o agente causador da doença (Almeida, Dantes, 2001, p.144).

Não bastaria produzir evidências na bancada do laboratório. Era preciso torná-las persuasivas, pô-las em circulação, granjear tantas adesões quantas fossem necessárias para converter a convicção partilhada por alguns em certeza coletiva, capaz de legitimar um conjunto de práticas de amplas consequências sociais. Como afirmou Jaime Benchimol (1999, p.263), as evidências produzidas em laboratório tinham de se sobrepor a conceitos e práticas enraizados entre médicos e leigos e se associar a interesses corporativos, econômicos e políticos que envolviam diversificado leque de atores.

Tentaremos mostrar como essa associação de interesses passava pelo disciplinamento do comportamento dos agentes econômicos, levados a sacrificar suas expectativas de ganho, quando as intervenções sanitárias se fizessem sentir no comércio e na exportação. Vejamos como exemplo a controvérsia envolvendo a epidemia de 1893. A imprensa rejeitou em peso o diagnóstico de cólera proposto por um grupo de jovens médicos liderados por ChapotPrévost e Francisco Fajardo, uma vez que reconhecer a sua existência imporia medidas muito mais restritivas à atividade econômica, o que por certo influiu em sua adesão à tese da disenteria. Por outro lado, conforme se atestava a eficácia profilática do diagnóstico, ficava cada vez mais evidente que as ações preconizadas pela nova política de saúde eram muito menos agressivas à ordem econômica e muito mais benéficas aos interesses dos cafeicultores e comerciantes urbanos. Esse processo começa com a imprensa desempenhando um papel ativo e concorrente na definição das doenças e termina com o reconhecimento social da autoridade sanitária como a instância legítima de formulação dos fatos biomédicos e das medidas profiláticas correspondentes, o que já seria uma realidade no primeiro decênio do século XX.

Para entender essa passagem, devemos remontar à complexidade técnica e ao imenso custo social da vigilância sanitária tradicional. Seguindo as instruções baixadas por Torres Cotrim em dezembro de 1894, na capital federal, ao acorrer ao domicílio onde fora notificada 
a presença de um caso suspeito ou confirmado, o comissário de higiene verificava se podia ser isolado e tratado ali. Uma vez afixado o cartaz da Diretoria-geral de Saúde Pública, os aposentos do doente permaneciam interditados por oito dias, no mínimo, e as pessoas que coabitavam ou conviviam com ele ficavam sujeitas a confinamento e inspeção diárias por cinco dias, para evitar qualquer manifestação de contágio (Cotrim citado em Benchimol, 1999, p.272).

Podemos imaginar a extrema impopularidade que cercava as medidas de interdição e desinfecção em uma cidade como o Rio de Janeiro, tomada por cortiços, velhas estalagens e habitações coletivas. Além de paralisar a economia e restringir a imigração, a profilaxia higienista despertava grande insatisfação nos setores populares dos principais centros urbanos. Ao mesmo tempo, a variedade e a dispersão dos objetos e dos corpos a inspecionar e isolar tornavam as operações de quarentena e desinfecção muito caras, descontínuas e pouco eficientes, o que dava ao apoio da imprensa e da classe política um peso fundamental nas controvérsias médicas sobre a definição da doença, durante as epidemias. Por sua vez, a política de saúde advogada pelos pastorianos simplificava o objeto da atenção sanitária e o alcance das medidas de contenção no tempo e no espaço, ao mesmo tempo que intensificava o monitoramento das condições de vida e o deslocamento dos corpos pela cidade. Ou seja, aumentava a capacidade institucional de vigilância sanitária, reduzindo seus custos sociais e políticos.

Estudos voltados para a demonstração estatística da ineficiência das desinfecções parecem ter tido um papel relevante no convencimento dos membros mais irresolutos da elite médica e na adesão dos políticos, dos comerciantes e da imprensa ao novo paradigma sanitário. Nesse quadro, merece destaque a obra Contribuição para o estudo epidemiológico da febre amarela, assinada por Bulhões Carvalho, responsável pela seção de demografia do Instituto Sanitário Federal. A pergunta principal é redigida de forma bastante direta: "a instalação do serviço regular de desinfecções influiu favoravelmente para evitar ou atenuar a extensão das epidemias de febre amarela?" (Brasil, 1903, p.3). Comparando o total de óbitos causados pela moléstia na capital federal, ao longo dos 13 anos anteriores e posteriores à criação daquele serviço (1890), o estudo não se detém na diferença absoluta de óbitos de cada período - 11.808 em 1877-1889 contra 22.506 em 1890-1902 -, praticamente o dobro. Alega que essa opção não respeitaria as causas que promoveram o aumento da mortalidade no segundo intervalo. Desagrega os dados relativos aos anos de menor incidência da doença em cada período, quando a febre amarela se manifestou apenas sob a forma endêmica, descartando as excepcionalidades características dos anos marcados por surtos epidêmicos.

Segundo Carvalho, no período de 1890 a 1902 houve anos, como os de 1897, 1900 e 1901, em que a febre amarela produziu apenas 159, 344 e 299 óbitos, respectivamente. Em contrapartida, no primeiro intervalo, os anos de 1877, 1881, 1882, 1885 e 1887 também figuram com obituários de pouca importância, respectivamente 282, 257, 89, 445 e 137. O número significativamente mais baixo de vítimas fatais em qualquer um desses anos, em contraste com os 984 óbitos de 1902 e os 559 do primeiro semestre de 1903, quando o serviço de desinfecção se encontrava plenamente instalado, seria a prova estatística de sua irrelevância profilática (Brasil, 1903, p.5). 
Mortalidade da febre amarella no Rio de Janeiro VALOR DAS DESINFECÇÕES

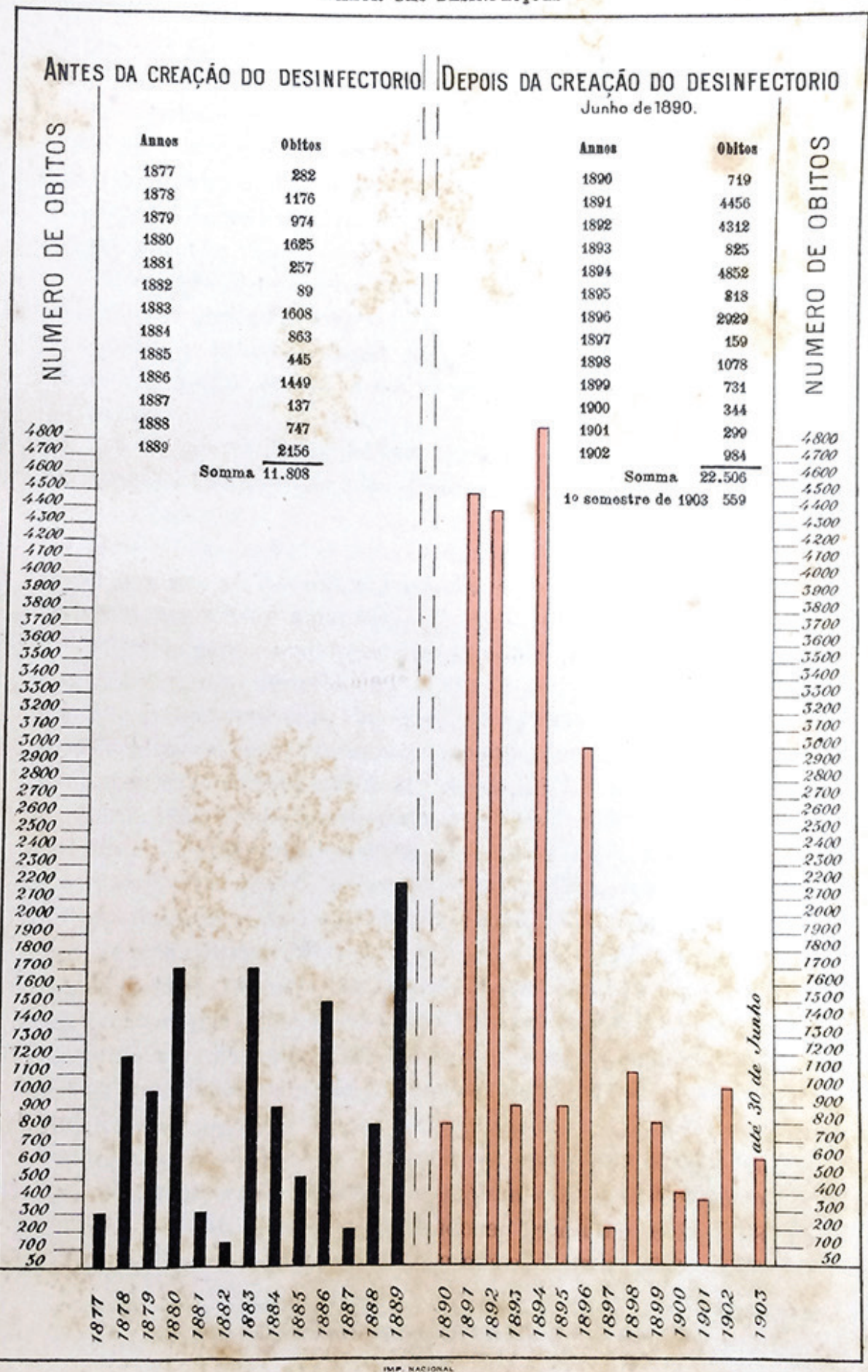

Figura 2: Mortalidade da febre amarela no Rio de Janeiro, 1877-1889 e 1890-1903 (Brasil, 1903, p.5-6) 
Com a criação do Instituto Soroterápico de Manguinhos (logo Instituto Oswaldo Cruz, IOC) e do Instituto Butantã, em São Paulo, ambos em 1900, temos o primeiro registro do que Latour (1988, p.253) chamou de circuito de tradução. Parte-se da situação anterior de não equivalência entre interesses - dos políticos, dos fazendeiros, dos higienistas e dos bacteriologistas - e chega-se a uma equivalência entre as proposições. Isso ocorreu com a vinculação bem-sucedida do destino da peste ao projeto dos sanitaristas e às aspirações dos cafeicultores, agora convencidos de que lutar contra a peste equivaleria a preservar o livre comércio no porto de Santos, o que era o primeiro passo para recrutá-los à causa de uma soroterapia brasileira. ${ }^{2}$

A função original dos institutos consistia na produção do soro antipestoso, em decorrência da peste que se alastrou em Santos, em 1899. Mas a rede de tradução, minuciosamente dissecada por Cukierman (2007), já estava posta e seria amplificada, com a promessa de erradicação da febre amarela da capital federal. Como colocou Latour (2000, p.117), o momento inicial de tessitura da rede é marcado pelo atrelamento de questões particulares (como o orçamento da ciência) às questões maiores (como a sobrevivência do país), que se tornam tão bem vinculadas, que ameaçar as primeiras equivale a ameaçar as últimas.

Como resultado da campanha urbana e sanitária de 1902-1906, e da demonstração estatística de seu êxito, o IOC ganharia unidades de pesquisa experimental e autonomia financeira, que lhe garantiria patentes sobre suas descobertas e contribuições científicas, além de participação na venda dos soros de sua produção. Não por acaso, o laboratório de pesquisa e a escola do IOC, que garantiriam a visibilidade internacional e o recrutamento autônomo, viriam imediatamente após a campanha de combate à febre amarela. ${ }^{3}$

Entre 1900 e 1907, a rede havia se ampliado por meio de novas traduções, graças à ascensão de Oswaldo Cruz ao comando da Diretoria-geral de Saúde Pública (DGSP), ${ }^{4}$ o que lhe permitiu acumular o braço científico e o burocrático da saúde, minando as últimas resistências internas que os pastorianos enfrentavam. Restaria a resistência da população, confirmada pela revolta de 1904, contra a obrigatoriedade da vacinação antivariólica. A reforma sanitária, empreendida com truculência e plenos poderes às brigadas de matamosquito, fez-se mediante a justaposição das competências previstas pela Constituição à União e à municipalidade do Distrito Federal.

Um obstáculo a ser vencido era a descontinuidade de interesses entre a DGSP e outras agências burocráticas. Assim, as deficiências na organização do registro civil, então a cargo da Diretoria-geral de Estatística, ameaçavam a qualidade das tão desejadas estatísticas vitais, base da demonstração da eficácia profilática do novo modelo. Para desatar esse nó, seria preciso remediar a principal dificuldade enfrentada na organização das estatísticas vitais, apontada por Telarolli Júnior (1993, p.150): o sub-registro de óbitos e nascimentos, a notação incorreta de idades e erros na definição de natimortos e óbitos infantis perinatais. A seção de estatística demógrafo-sanitária do Serviço Sanitário de São Paulo, durante as duas décadas iniciais de atuação, ficou restrita à capital, uma vez que quase nenhuma informação provinha do interior. Mesmo na capital, eram constantes os problemas de remessa irregular de registros civis.

No federalismo oligárquico, a obtenção regular das informações não poderia ser garantida apenas por lei ou decreto, frequentemente descumpridos, porque emanados de uma 
autoridade estatal de reconhecimento limitado, que dependia da associação com poderes locais e privados para governar. Uma das principais dificuldades da rede médico-científica consistiria justamente em trazer atores diversos e dispersos para a perspectiva sanitarista, que só cederiam suas vontades quando seus interesses particulares fossem vinculados ao interesse geral identificado a um projeto de centralização.

É esse movimento que começamos a assistir na década de 1900, quando se tornava claro para os sanitaristas que a rede médico-científica dependia da estabilização dos registros e das margens de interpretação da estatística. Para tanto, seria preciso tornar obrigatória a notificação compulsória dos óbitos por doença. Na capital da República, ela foi assegurada pela implantação de um serviço permanente de verificação geral de óbitos, ainda em 1902. Tratava-se aqui de supervisionar a prática dos clínicos, constrangendo-os a observar um procedimento burocrático que cerceava sua autonomia, indicando que o arsenal tradicional de saberes e técnicas empregado em consultórios e hospitais não poderia dar conta do tratamento dos diversos estados mórbidos.

Nos anuários demográficos da capital federal e de São Paulo, é recorrente a presença de exortações à classe médica para que passasse a assimilar em sua prática o recurso aos exames laboratoriais para a identificação de doenças que, de outro modo, seriam rotuladas pela evolução dos sintomas relatados nas queixas do doente, no depoimento dos que o assistiam ao leito e, principalmente, pelo exame do médico que, auscultando suas entranhas, estabelecia a leitura exegética dos sinais (Alves, 1999, p.81). Na ausência dos exames laboratoriais, a designação "erro de diagnóstico" passa a ser empregada para presumir a omissão na utilização dos novos recursos normativos.

Desenhavam-se, assim, uma intervenção permanente e uma distância sobre a sintomatologia médica, corrigindo os "vícios" e os "erros de notação" do clínico e levando-o a ver o que os pastorianos viam desde seu laboratório e desde seu observatório estatístico. Uma intervenção que logo não seria percebida pelos próprios clínicos como uma ingerência, à medida que o novo protocolo observacional se acomodasse em sua rotina profissional, o que era indispensável à estabilidade da rede e à demonstração estatística de sua eficiência, capaz de apontar para sua desejável expansão, para outras moléstias - como a tuberculose e para outros espaços - como os subúrbios do Rio de Janeiro.

A leitura dos relatórios do Ministério da Justiça indica que a agenda médica encontrava amplo respaldo na classe dirigente já nos anos imediatamente anteriores à reforma sanitária do Distrito Federal. O relatório de 1901-1902 é emblemático. Adverte que "o Estado, quando confere ao médico as honrarias e prerrogativas do exercício profissional, não cuida de obsequiar o indivíduo com privilégios e favores, mas visa o interesse da coletividade", que, a partir daquele momento, passava a incluir "a notificação compulsória das moléstias transmissíveis, recentemente tipificada pela legislação sanitária" (Brasil, 1902, p.291), cabendo aplicação de multas aos infratores. Outra tradução bem-sucedida, diretamente ligada ao reconhecimento do monopólio médico sobre o registro de óbito, era o entendimento de que a quarentena dos portos havia caducado, tornando-se ultrapassada: 
o regime quarentenário tem seu canto do cisne. Preconiza-se a necessidade de organização da defesa interna, já que a externa se torna insuficiente: a detenção dos navios em lazaretos é agora substituída pelo expurgo das matérias contaminantes e pela vigilância médica dos desembarcados. A instituição da higiene agressiva, pelo saneamento do meio, parece a todos o sumo objetivo das administrações. Numa época em que a atividade comercial está avassalando o mundo, os interesses mercantis preponderam no lema do no restraint (Brasil, 1902, p.296).

Como se depreende da leitura dos relatórios, a coalizão de forças resultante da tradução de interesses havia atingido diferentes níveis: a defesa do monopólio médico do registro de óbito; o disciplinamento do olhar clínico sobre a notificação das moléstias, base do diagnóstico; a desautorização da quarentena e da desinfecção como medidas profiláticas; o saneamento como fonte de controle e combate aos focos; o monitoramento estatístico e a prevenção das doenças. Começava a se desenhar no discurso oficial a percepção da interdependência socioespacial das doenças, embora ainda restrita ao âmbito da capital da República.

Essa percepção se refletia na ampliação das competências da DGSP. Ao longo da gestão Oswaldo Cruz, foram incorporados os serviços de higiene defensiva no Distrito Federal, a polícia sanitária, a profilaxia geral e a higiene domiciliar. Foram também criados o Serviço de Profilaxia da Febre Amarela e o Regulamento Processual da Justiça Sanitária. Tais medidas apontam para um movimento de coordenação da atividade sanitária. Ficava, entretanto, mantida a dualidade entre a responsabilidade federal sobre os portos e o Distrito Federal, e a dos estados sobre seus respectivos territórios, permanecendo excepcional a ação da DGSP fora desses limites (Hochman, 2001).

\section{Um monumento estatístico para a reforma sanitária}

Nesta seção, veremos como o censo de 1906 e os relatórios da DGSP dos anos imediatamente seguintes compuseram um conjunto destinado a monumentalizar a reforma sanitária do Distrito Federal e a expandir o programa de doenças que até então baseava a ação em rede.

O censo do Rio de Janeiro de 1906 se destaca por uma perspectiva fortemente sanitarista sobre a população. Ela se revela tanto no tratamento privilegiado de temas ligados à saúde quanto na importância central atribuída à densidade demográfica, chave para o zoneamento sanitário da cidade e a visualização dos focos epidêmicos e suas manifestações endêmicas. A densidade também importava como meio de visualização das moradias urbanas, cuja inspeção e regulação era uma das principais estratégias para o saneamento da cidade. Nesse sentido, um segundo volume, inteiramente dedicado à estatística predial, respondia por cerca de metade da publicação, destacando os níveis de aglomeração e as condições sanitárias de habitação e coabitação, alvo da política de saúde que então se implantava.

Instrumento da reforma sanitária, organizado por Aureliano Portugal, o demógrafo sanitarista que respondia pela inspetoria de higiene do Distrito Federal, o censo não se deteve na preferência pelos temas de saúde. As demais variáveis, como a composição 
etária, a instrução e a ocupação da população foram trabalhadas com o fim de realçar a "vitalidade" da população brasileira e natural da cidade, em relação ao desempenho que os imigrantes apresentaram nessas mesmas variáveis. Assim, a distribuição por sexo e fecundidade apresenta a composição e o crescimento relativo dos dois grupos. $\mathrm{O}$ coeficiente de natalidade por mulher, que daria a ver a fecundidade, não é comparado por ser inferior a $120 \%$ entre os nacionais. O percentual, julgado "muito baixo", é atribuído às "deficiências do registro civil" e às "condições especiais no tocante à imigração que se fixa na cidade", que dispensam a comparação (Brasil, 1907-1908, p.81). Quanto ao estado civil, uma superioridade brasileira. As proporções de solteiros, casados, viúvos e de mulheres relativamente a homens mostra-se favorável aos nacionais, grupo que apresentava maior presença relativa de solteiros e, portanto, maior potencial de crescimento e fecundidade.

A grade da vitalidade transparece, ainda, na avaliação da instrução e da ocupação. A primeira se esgota na mera verificação da alfabetização, sem nada dizer sobre escolaridade ou frequência escolar. Confrontado com o dado de $48,1 \%$ de analfabetos no que era a vitrina do país, o organizador do censo limita a desagregá-lo por nacionalidade, contentandose com a demonstração da menor participação relativa dos estrangeiros, especialmente portugueses, espanhóis e italianos, entre os 51,9\% de alfabetizados.

O mesmo censo traz uma leitura da ocupação ainda mais controversa. É o primeiro a se alinhar à normalização internacional sugerida para o tópico, classificado segundo setores produtivos: "produção de matérias-primas", "transformação de matérias-primas"; "administração pública" e "profissões liberais". Dois dados chamam atenção. Primeiro: para a comissão censitária, o fato de os estrangeiros representarem cerca de $50 \%$ da totalidade de pessoas empregadas no segundo setor (indústria e manufatura) é "compensado" pela participação em quase $90 \%$ dos brasileiros na classe de "administração pública e profissões liberais", sem mencionar que essa compõe apenas $6 \%$ da população total, ou seja, a pequena burocracia e uma elite de políticos e intelectuais. ${ }^{6}$ Tal como a instrução, a ocupação é mais um indicador da vitalidade da população. Segundo: o fato de uma quarta categoria, "diversas", que agrupa trabalhadores domésticos e braçais, "profissões mal especificadas" e "classes improdutivas", responder por cerca de 70\% do total da população ocupada. Cifra que, paradoxalmente, tornava inútil o modelo de codificação da estrutura ocupacional. Um modelo originalmente concebido para uma economia industrial e que se aplicava muito mal a um país fortemente marcado por formas intermediárias de trabalho dependente, no campo, e até mesmo na cidade.

Saúde e educação encontravam-se, então, longe de serem associadas pela via da educação sanitária, ao contrário do que sucederá a partir da conjuntura de guerra e da descoberta sanitarista dos sertões. O mesmo sucede em relação à ocupação, tabelada e analisada sem qualquer referência à destituição e ao abandono, característicos da fase nacionalista. Era possível seguir indiferente à sua hostilidade ao Estado, nesse primeiro momento, uma vez que o programa sanitário se concentrava sobre as doenças controláveis pela combinação de medidas de higiene agressiva e um regime de profilaxia que podia ser imposto "por cima", pois não dependia da reforma dos hábitos nem da alteração das condições de vida, moradia e alimentação da população. 


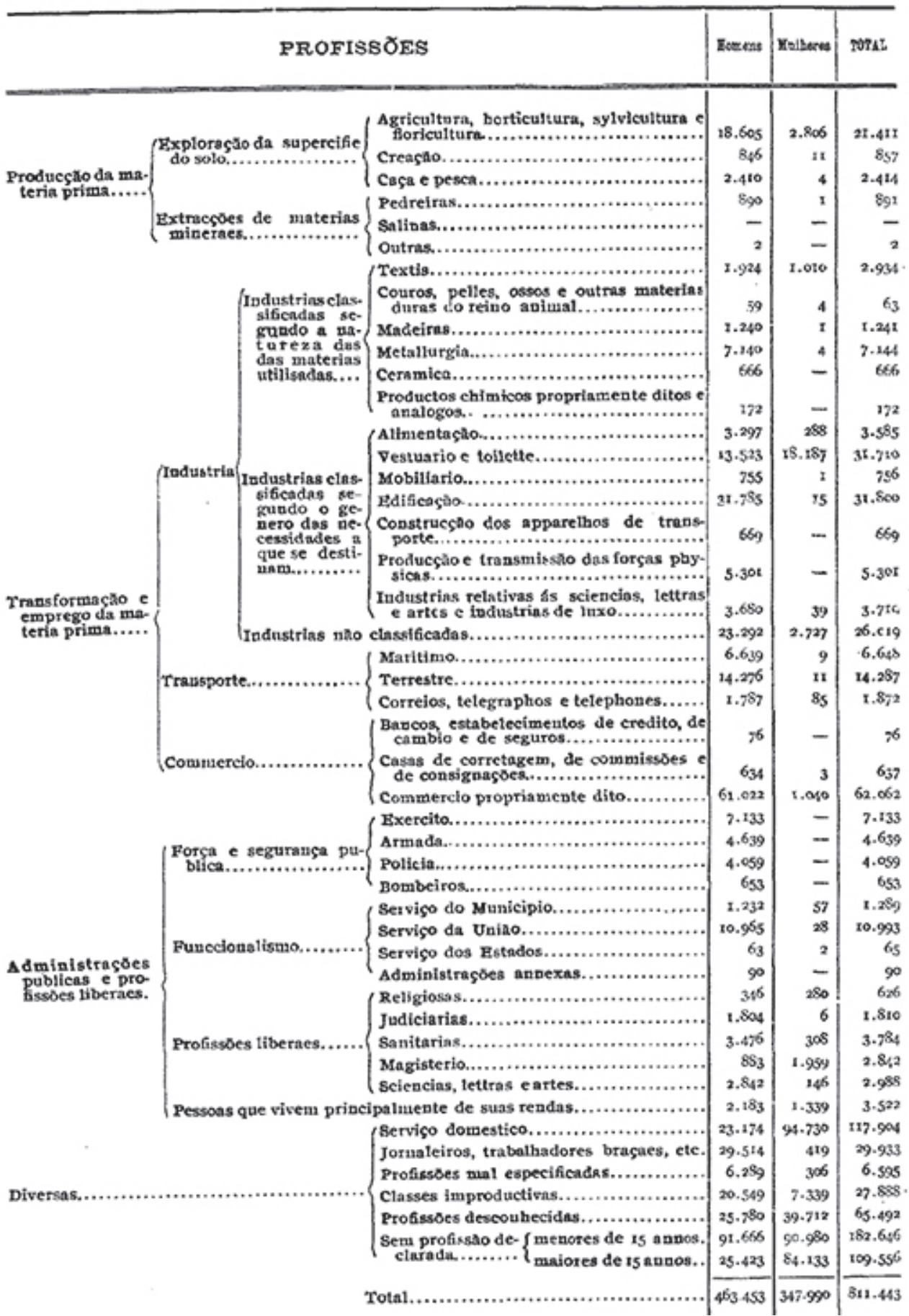

Figura 3: Profissões por sexo no Rio de Janeiro, 1906 (Brasil, 1907-1908, p.104) 
Essa mudança deve ser buscada, de forma indiciária, nos anexos da DGSP e da seção de demografia sanitária constantes no relatório ministerial, cobrindo o intervalo que decorre entre o censo de 1906 e a publicação das memórias da expedição de Artur Neiva e Belisário Pena, em 1916. É possível dividir os relatórios em dois momentos. Entre 1904 e 1907, são destacados os quadros estatísticos que dispõem a mortalidade da febre amarela por nacionalidade, sexo e idade, ao longo do período que se estende de 1873 a 1897, sobressaindo um padrão de ciclos epidêmicos, alternados por manifestações da doença sob a forma endêmica. Somos levados a ver que ela sempre esteve presente entre nós, desde a primeira epidemia. Outro conjunto de tabelas reforçava o contraste produzido em muito pouco tempo. Com títulos como "Influência da nova profilaxia sobre a mortalidade da febre amarela", tabelas e diagramas atestavam a velocidade e o êxito da campanha empreendida entre 1902 e 1906, enfatizando a redução a quase zero no número de casos.

Um ponto de inflexão aparece nos relatórios subsequentes à reforma sanitária da capital, quando a profilaxia da tuberculose passa a ganhar importância entre os alvos da saúde pública. Os elevadíssimos níveis que atingia a moléstia entre nós, antes relativizados pela companhia de coeficientes mortuários semelhantes encontrados em cidades como Paris e Viena, agora começavam a se transformar no grande inimigo. Antes, o argumento de que se tratava de uma moléstia estabilizada, que matava há anos com a mesma regularidade, indicava um "descontrole sob controle", que lhe assegurava um processo natural de domesticação, desde que mantida em um patamar estatístico determinado, ao contrário do que se verificava nos paroxismos epidêmicos do trio febre amarela-peste-varíola.

A partir de 1907, será justamente o caráter estável e crônico da doença a razão da urgência em combatê-la. Comunicação apresentada pelo "demografista" Bulhões Carvalho (1907, p.13) ao terceiro Congresso Médico Latino-americano, de 1907, já dispunha as informações de maneira a contrastar a grande redução nas mortes por febre amarela, peste, febre tifoide, disenteria, beribéri e paludismo com a extrema regularidade das vítimas da tuberculose, levando seu autor a exortar: "é agora ocasião de fazer mais alguma coisa, encarando de perto e resolutamente o problema da profilaxia da tuberculose, esta inimiga insaciável das coletividades, esse 'minotauro da humanidade', na feliz expressão de notável escritor".

Na mesma linha, o relatório ministerial de 1907 aponta a tuberculose como o grande impulsionador da mortalidade geral, a exigir o aprofundamento da reforma sanitária. Segundo Oswaldo Cruz, diretor-geral de Saúde Pública, "a mortalidade geral decresceu e, mais ainda, desceu a porcentagem das moléstias infectuosas em relação à mortalidade geral". Infelizmente, porém, esse decréscimo não teria como atingir a cifra tão esperada: "se examinarmos a curva das chamadas moléstias evitáveis, veremos que quase todas sofreram uma sensível diminuição, à exceção de uma que continua a ceifar as vidas na maior pujança de sua atividade produtiva. A tuberculose quase não foi influenciada pelas medidas sanitárias postas em prática. E não o foi porque não foi feita sua profilaxia específica" (Brasil, 1907, p.3).

De início, a ênfase dos relatórios gira em torno da criação de moradias populares e da adoção de medidas profiláticas indiretas, destinadas a atacar os fatores socioambientais que poderiam comprometer a luta do organismo contra os bacilos que produzem a moléstia: "forneçam-se habitações higiênicas, alimentação abundante e boa, não se permita o trabalho 
MORTALIDADE DA FEBRE AMAREI.LA. 38, 1 -1906.

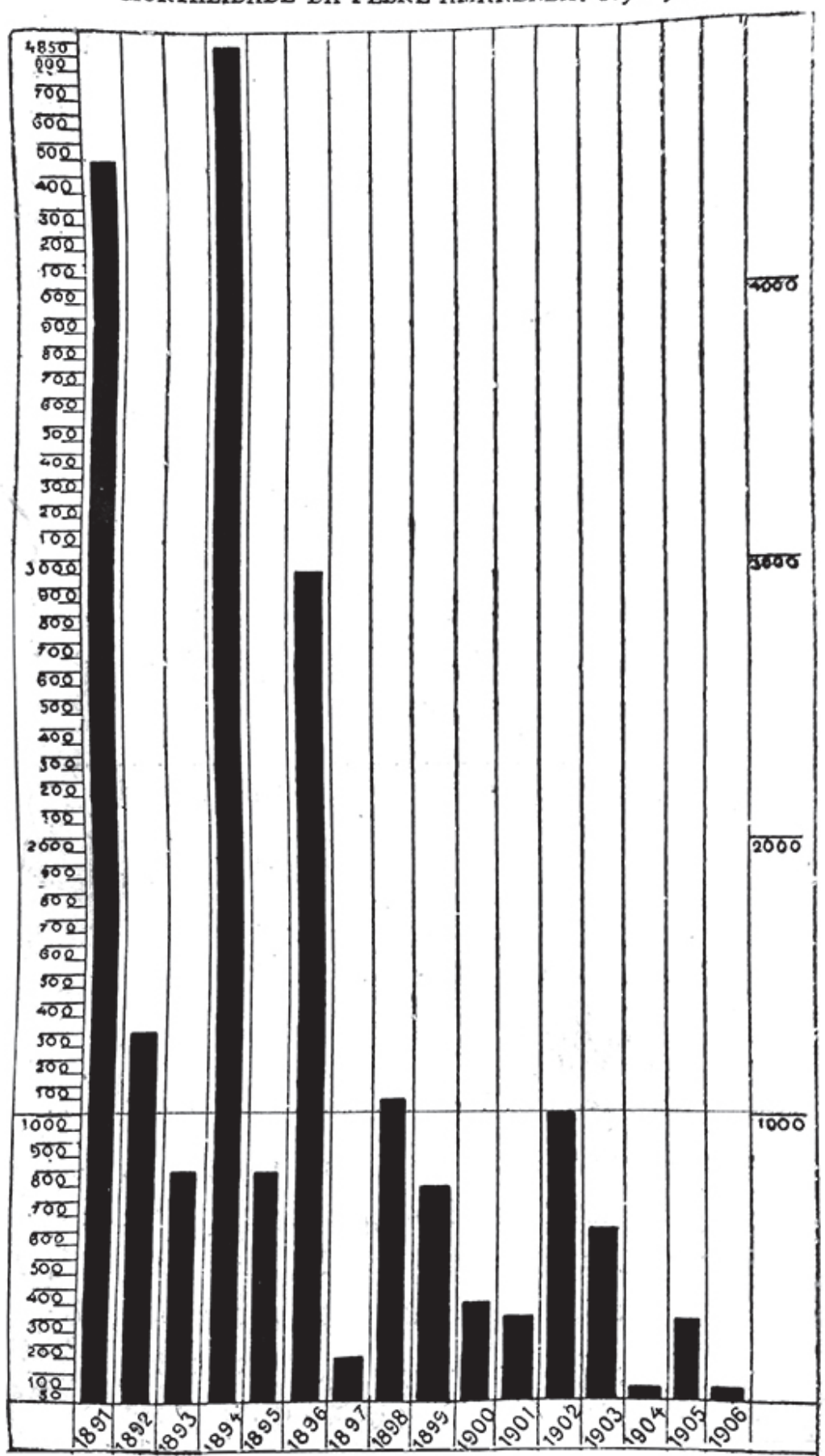

Figura 4: A prova estatística da neutralização da febre amarela (Brasil, 1907, p.5) 
das crianças nas fábricas, proceda-se à lavagem das roupas, evitem-se os esgotamentos orgânicos de causas higiênicas, morais e físicas", de modo a produzir "um organismo resistente contra o bacilo assaltante" (Brasil, 1907, p.4). Enquanto não fosse possível eliminar o bacilo do meio circundante, o alvo da atenção médica deveria recair sobre os "indivíduos tuberculisáveis, que se encontram em condições excepcionais de receptividade para contrair a moléstia" (p.4).

O relatório referente a 1913 é o primeiro a destacar "a falta de higiene no trabalho, a nutrição insuficiente, o alcoolismo, e a miséria como obstáculos à ação profilática" (Brasil, 1915, p.54-55). Ao mesmo tempo, o volume de páginas reservado à descrição da tuberculose na seção sobre as moléstias infecciosas vai sendo ampliado. Igualmente interessante é a construção estatística da tuberculose como nova doença prioritária no programa sanitário. A disposição visual dos óbitos passa a incluir sua desagregação por meses do ano, sexo, idade, estado civil, cor, nacionalidade e circunscrição de origem, refinando o tratamento numérico da sua extensão. Os coeficientes mortuários são confrontados para enfatizar justamente o que antes se queria atenuar e omitir dos gráficos e diagramas: a letalidade superior da tuberculose em relação à febre amarela, ao longo de quase todos os anos cobertos pela série histórica.

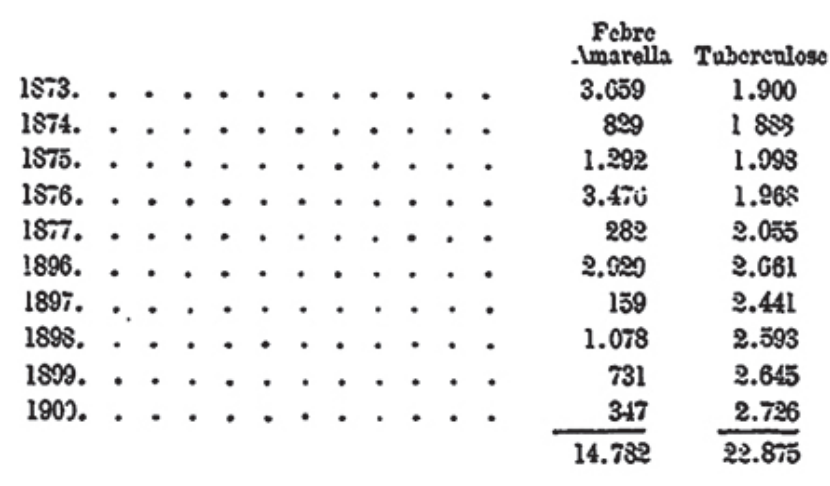

Ax:OS DE 1802 A 1907

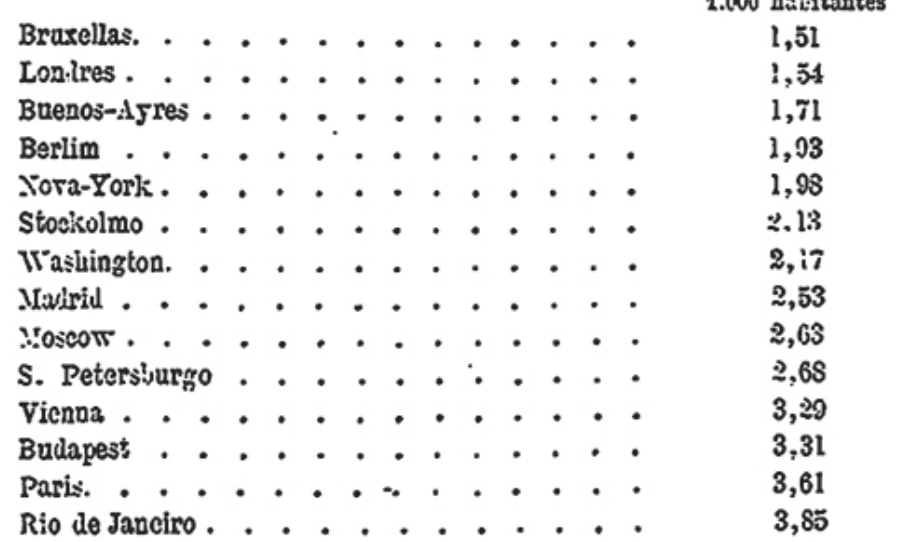

Figura 5: Mortalidade da tuberculose no Rio de Janeiro (1873-1900) e nas capitais mundiais (1902-1907) (Brasil, 1909-1910, p.10) 
Do mesmo modo, a comparação com os índices de outras capitais estrangeiras, que antes ajudava a relativizar a participação da tuberculose na mortalidade geral, agora realçaria o estado de alarme, "justificando a intervenção do governo na campanha contra esta funestíssima moléstia" (Brasil, 1910, p.10). Realçava-se sua saliência para a salubridade da cidade, assim como a eficácia dos meios científicos para combatê-la, exemplificados e monumentalizados a cada novo quadro, a cada novo relatório, a cada novo ano.

\section{A quantificação da saúde nacional}

Nas décadas de 1890 e 1900, a construção da autoridade sanitária e a implementação da nova política de saúde foram viabilizadas, sobretudo, pela tradução de interesses dos médicos e das elites políticas e oligárquicas, deixando praticamente intocada a negativização do elemento popular e sua interpelação como antissujeito ético, indolente e indisciplinado por excelência. A inclusão das doenças crônicas e das endemias rurais mudará esse quadro, insuflando o movimento nacionalista e um novo olhar sobre o homem médio do Brasil.

A doença de Chagas constitui um elo importante nessa passagem. Identificada em 1909, logo seria representada, simultaneamente, como entidade médica e questão nacional. Como mostrou Simone Kropf (2009), Carlos Chagas - graças à rede previamente organizada construiria a moléstia como uma moldura para a sociedade, ao permitir descortinar os males do Brasil: as endemias rurais. Nessa conta, a doença deveria servir de bandeira para que o Estado promovesse o saneamento dos sertões (Kropf, 2009, p.131), o grande tema da mobilização nacionalista que se desencadeia a partir de 1916. Ao tornar o bócio endêmico, extremamente disseminado entre as populações rurais do Brasil, um dos sintomas principais da doença, transformando-o em uma decorrência da ação patogênica do barbeiro sobre a tireoide, a ação em rede ampliou a tradução para as doenças crônicas e degenerativas que comprometiam o desenvolvimento orgânico dos indivíduos.

A chamada "questão nacional" surge com força no contexto da Primeira Guerra Mundial, em uma confluência entre a geopolítica internacional e a conjuntura social e política (Oliveira, 1990). Para fazer frente a uma eventual participação no conflito, procede-se a um alistamento militar, que se mostra um fracasso completo. As ligas nacionalistas foram fundadas, aproximando as forças armadas da perspectiva sanitarista, combinando-se a visão de salvação nacional do Exército e do tenentismo à ênfase na inanição, na doença e no abandono do interior brasileiro. Mais do que expor a soberania do país, esse quadro precipitou uma consciência da nacionalidade, ligando-se às então recentes ações de saúde pública nos centros urbanos para afirmar a necessidade de saneamento físico e moral dos sertões. Enquanto a tuberculose foi construída como causa principal da mortalidade "evitável" nas grandes cidades, a febre amarela, a malária e a ancilostomíase constituíam o flagelo "evitável" dos sertões, as endemias rurais que baseariam os acordos sanitários pela cooperação entre os poderes.

Esses acordos tiveram na transferência da higiene do Distrito Federal para a União a sua gênese, entendendo-se que seus problemas sanitários afetavam o restante do país e as relações dele com o exterior - na aquisição de empréstimos, na atração de imigrantes etc. A penetração do poder central continuaria por meio de comissões federais de combate à 
febre amarela e com os primeiros acordos para os programas de saneamento e profilaxia rural entre a União e os estados. Como mostrou notável estudo de Gilberto Hochman (2012), inicialmente a colaboração se deu por medidas pontuais e isoladas, como a distribuição gratuita da quinina aos estados, o que contornava as alterações constitucionais e a necessidade de beneplácito do Legislativo. Depois, viria o Serviço de Profilaxia Rural, instituindo a possibilidade de acordo com os estados para o saneamento rural (p.138).

Criado em 1920, o Departamento Nacional de Saúde Pública (DNSP) consistiu na expressão institucional do movimento de coordenação da atividade sanitária, substituindo e ampliando as atribuições e o alcance da DGSP. O novo departamento correspondeu na prática a uma reforma na estrutura da saúde pública brasileira, em particular pelo aumento da capacidade do governo federal para atuar além dos limites da capital do país e dos principais portos marítimos e fluviais, e pela incorporação formal, pelo Estado nacional, da preocupação com as doenças das populações do interior, como a ancilostomíase, a malária e a lepra (Hochman, 2001).

A atuação do DNSP e o novo programa sanitário, com foco na tuberculose e nas endemias rurais, procuravam reverter a tradicional hostilidade da população à autoridade estatal, por meio de seu recrutamento como sócia na empresa coletiva de gestão da higiene. Isso significaria agir no tecido da sociabilidade, de modo a modificar hábitos arraigados, como o consumo de álcool, a prostituição, a não utilização de calçados e latrinas, o despejo de lixo em rios e vias públicas, a manutenção de focos de moscas, ratos e mosquitos, a fraude no leite e nos alimentos, entre outros.

Escolas foram criadas como anexos aos postos sanitários, enquanto as escolas existentes adotavam cartilhas de educação sanitária. Os professores primários recebiam treinamento em cursos de higiene, para que, durante sua rotina em sala de aula, pudessem apoiar as campanhas profiláticas de doenças e disseminar conhecimentos práticos sobre saúde e higiene junto a seus alunos, os quais, uma vez introduzidos nesses temas, tornavam-se vetores da reorientação dos pais.

Com o objetivo de difundir os preceitos da educação sanitária, o DNSP organizou atividades que buscavam a adesão da população para o aceite de práticas consideradas ideais pelas autoridades, principalmente na higiene pessoal e na saúde das crianças e gestantes. Para atingir esse objetivo, um de seus órgãos subordinados, o Serviço de Propaganda e Educação Sanitária, fez extenso uso de cartazes, folhetos, jornais ilustrados, transmissões de rádio e filmes destinados à educação popular. Por sua vez, o Serviço de Enfermagem foi responsável pela orientação das visitadoras de higiene, que tinham a finalidade de percorrer as residências de forma a esclarecer a população sobre a necessidade de hábitos higiênicos (Souza, 2012, p.23). A cooperação com a imprensa era constante, vinculando conteúdos educativos com frequência diária nos jornais do país. Dessa forma, buscava-se articular o diagnóstico precoce e a prevenção por meio da divulgação das características das enfermidades e da informação sobre suas profilaxias (p.27).

O discurso e as práticas de quantificação endossaram o projeto de coordenação da atividade sanitária. $\mathrm{O}$ anuário estatístico, por exemplo, foi empregado como instrumento de visualização da interdependência espacial das doenças e, nessa condição, contribuiu para um projeto de centralização da autoridade sanitária que não disputasse a 
descentralização política, verdadeira moldura do Estado sob o federalismo oligárquico. O único anuário estatístico nacional produzido na Primeira República (relativo a 1912 e publicado em 1916) tabula as informações de maneira a reforçar a comparação e a desigualdade entre os estados. Os dados relativos ao Distrito Federal ajudaram a monumentalizar a reforma sanitária havida no Rio entre 1902 e 1906, e a impô-la como modelo aos estados mais assolados pelas doenças transmissíveis, especialmente aquelas já erradicadas na capital federal.

A disposição das informações, reservando uma página para o Distrito Federal e outra para os estados, permitia um confronto direto, evidenciando a redução em cerca de $40 \%$ do total de "óbitos por moléstias", em favor do primeiro, contra a elevada incidência ou a redução residual verificada para o conjunto dos estados no período considerado (Brasil, 1916, p.420-424). Para realçar ainda mais esse desnível, um gráfico sobre o coeficiente mortuário dispõe as moléstias transmissíveis nas capitais não mais no padrão da ordem alfabética, mas por ordem de ocorrência, especialmente de óbitos (p.426).

Essa opção revelava que seis das dez capitais em situação mais crítica de mortalidade geral se encontravam no norte do Brasil - que, então, incluía o atual Nordeste. A disparidade regional ficava mais acentuada quando se consideravam as doenças transmissíveis, especialmente mortais em Recife, Manaus e São Luís, que ostentavam índices muito acima da média geral do país. E que os subúrbios do Distrito Federal, assim como o estado do Rio de Janeiro (mesmo a capital Niterói), ainda sofriam com as doenças transmissíveis - que exigiam dos governos ações sistêmicas de higiene agressiva - e, assim como a capital da República, padeciam com os altos índices de tuberculose, que só seriam remediados por um forte e inédito investimento em higiene preventiva (Camargo, 2015, p.89-90).

Paralelamente, a quantificação dos aparelhos sanitários criados pelos acordos de cooperação entre a União e os estados dava a medida da cobertura que se queria expandir e nacionalizar. Diante da ausência de agências produtoras de dados em grande parte dos estados e municípios, foram os inspetores de saúde dos portos e os chefes dos serviços de saneamento rural nos estados que passaram a receber as informações nos locais em que se encontravam organizadas e a enviá-las à Diretoria de Inspetoria Sanitária do DNSP. Nos lugares onde isso não ocorria, funcionários federais recorriam aos juizados de paz e cartórios para coligir as informações sobre óbitos, nascimentos e natimortos. Tratava-se de um esforço para montar uma base de informações nacional, não restrita apenas aos estados que tinham serviços sanitários mais organizados, levando a acordos que consagraram o modelo de declaração de óbito adotado pelo DNSP - base da estatística de mortalidade por doença -, impondo-o a todos os estados conveniados (Hochman, 2012, p.191; Fraga, 1928).

Os números relativos a atendimentos, exames, vacinações, revacinações e tratamentos eram regularmente coligidos e publicados em jornais e periódicos especializados, como $O$ Brasil Médico. Destacavam-se, assim, o crescimento e a efervescência dos postos de profilaxia rural, do serviço de proteção à infância e do serviço de inspeção escolar, os três principais espaços de higiene nas zonas suburbanas e rurais, instalados em diferentes cidades ao longo dos anos 1920. Os dados eram organizados a partir das estatísticas vitais produzidas pelos postos sanitários e apresentados como prova de eficiência do modelo de ação defendido pelo movimento. 
Coffsciente medio annaal' poe looo Rabitantes, da natafidade mpeciafidade o moitifidade no periodo de 1908 a $19 / 2$

Legenda

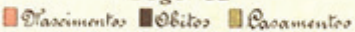

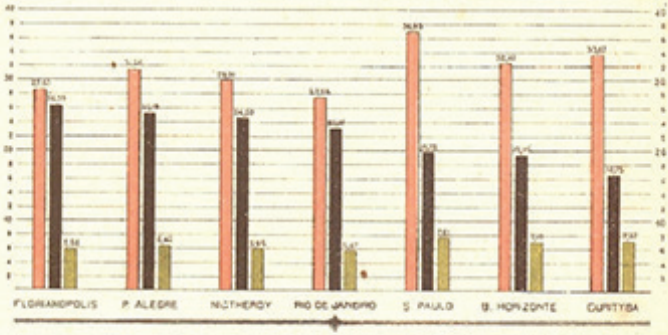

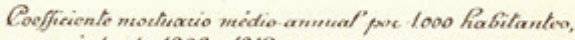
no preciodo de 1908 a 1912
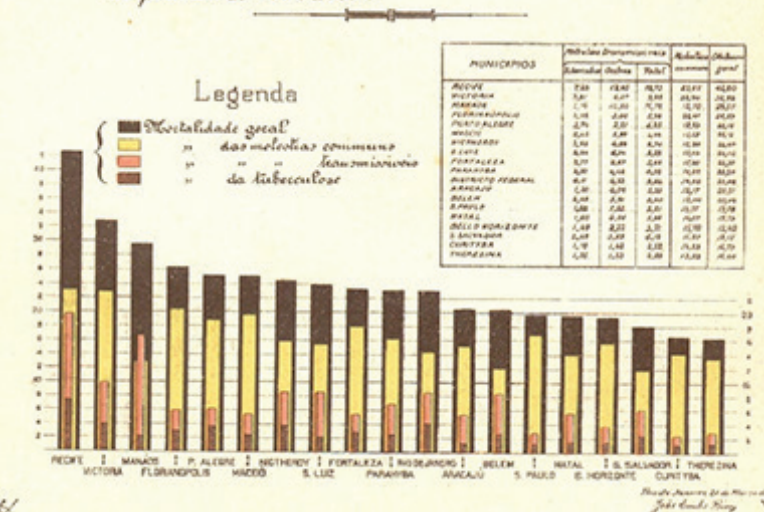

Figura 6: Coeficiente mortuário médio anual das capitais e do Distrito Federal, 1908-1912 (Brasil, 1916, p.426)

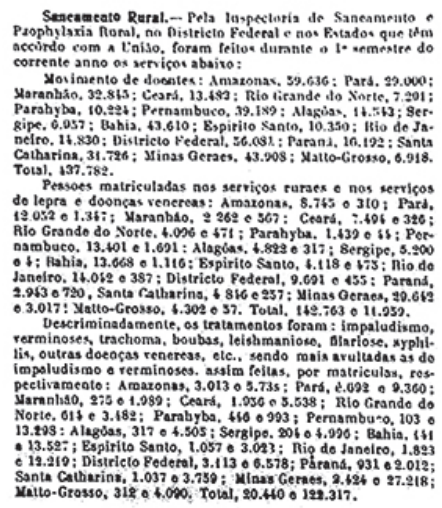

Figura 7: Desempenho e cobertura dos acordos de profilaxia rural em diferentes estados, 1923 (O Brasil Médico, 22 dez. 1923, p.372) 
Do mesmo modo que a experiência pregressa do Distrito Federal, onde a demografia havia sido um instrumento de validação da nova política de saúde e de expansão do programa sanitário, as estatísticas vitais foram empregadas para dar visibilidade às doenças venéreas e dimensionar sua extensão como um "flagelo nacional", justificando assim sua inclusão entre as endemias contempladas pela ação federal. Cabral (2007) e Carrara (1996) mostraram que os dados da lepra e da sífilis foram inicialmente compilados pelos médicos com base nos registros dos poucos estados e municípios em que tais doenças integravam a pauta dos serviços sanitários, visando confirmar o potencial de risco econômico e social que representavam para a sociedade brasileira. Tratava-se de uma combinação entre estatísticas hospitalares e governamentais, porém, locais e dispersas. Mesmo assim, esses números foram peça fundamental para a federalização do combate à lepra e à sífilis, fornecendo a prova material de seu incremento no país (Cabral, 2007, p.273).

A institucionalização veio com a criação da Inspetoria de Profilaxia da Lepra e Doenças Venéreas - outro órgão subordinado ao DNSP -, em 1922. As estatísticas produzidas pela agência se tornavam a expressão oficial das duas doenças no país, colocando em questão a atuação do poder público e a eficácia das medidas sanitárias executadas pela inspetoria. O alarme estatístico que havia acompanhado as reivindicações pela intervenção da União agora seria atenuado com o fim de subsidiar a política de isolamento do leproso e contornar a imagem de "país da lepra", embora os números colocassem o Brasil entre as nações mais afetadas no mundo (Carrara, 1996, p.119; Cabral, 2007, p.274-276).

Esse fato nos recoloca diante dos limites das práticas de quantificação. Como postulou Theodore Porter (1995), a importância crescente da objetividade mecânica na ciência e na vida pública, isto é, a preferência sistemática por protocolos e técnicas analíticas padronizadas em relação ao julgamento puramente baseado na prática pessoal e na experiência profissional, dependeu da competição por recursos escassos no processo de diversificação das elites burocráticas. Uma vez que não havia atores e corporações que rivalizassem ou disputassem os significados dos dados e das categorias fora do meio médico-científico, as estatísticas vitais jamais chegaram a basear projetos concorrentes de nação e de saúde.

O processo de centralização da autoridade sanitária teve nas estatísticas vitais um importante meio de comprovação da eficiência do modelo de ação, de demanda por recursos junto ao Legislativo e de expansão da competência dos serviços de saúde. Entretanto, as estatísticas vitais jamais forneceram um marco impositivo para estabelecer os focos prioritários de intervenção e alocação de recursos. Antes, porém, permaneceram uma tecnologia secundária de validação da hierarquia das doenças e do programa formulado pelos médicos e pela rede sanitarista, que, assim, delimitavam o campo de possibilidades do uso dos números nos debates da Primeira República.

\section{Considerações finais}

Diferentemente do que nosso argumento pode ter dado a entender em algumas passagens, o triunfo da bacteriologia não foi um fenômeno de direção linear. Ao contrário, comportou avanços e recuos, tensões e negociações, além de soluções de compromisso, como os esforços de importantes médicos do período em conciliar a tese pastoriana do combate 
à causa única e antigos postulados do ambientalismo. ${ }^{7}$ Contudo, nosso propósito aqui foi realçar o concerto de fatores que geraram uma mudança social mais ampla: a quantificação dos fatos biomédicos ajudou a impulsionar a construção da autoridade sanitária, e o fez de maneira a não colocar diretamente em xeque a descentralização política característica do federalismo oligárquico. Inversamente, a unificação da autoridade sanitária forneceria as equivalências de posições e interesses necessárias para produzir a confiança nas estatísticas oficiais, bem como seu uso na formulação de problemas públicos.

Nos anos 1890, os boletins e anuários de demografia sanitária compuseram o arsenal dos higienistas para impor o diagnóstico pastoriano e disciplinar o certificado de óbito produzido pelos clínicos, por meio do cumprimento de protocolos observacionais. Embora os boletins e os anuários não servissem de subsídios factuais determinantes para as ações sanitárias do final do século XIX e início do XX, serviam como registro dos efeitos dessas campanhas e como prova de sua eficácia. É exatamente o que vimos na monumentalização estatística da erradicação da febre amarela, da varíola e da peste, que ajudaria a sustentar a expansão do programa sanitário para outras doenças, como a tuberculose.

Nos anos 1910 e 1920, a estatística demográfica vai assumir uma dimensão nacional, no processo que generaliza a perspectiva sanitarista para o conjunto da sociedade, agora na qualidade de um movimento nacionalista. O anuário estatístico do Brasil é o primeiro a dispor as informações de maneira a apontar as disparidades no desenvolvimento dos estados e, assim, fundamentar a centralização da autoridade sanitária. As estatísticas das doenças venéreas, por sua vez, ajudaram a ampliar as zonas de visibilidade do programa sanitário. Uma vez incluídas na estrutura burocrática do DNSP, a gravidade do quadro que os números descreviam seria atenuada, de maneira a proteger a difusão do novo modelo de ação, cuja eficiência era continuamente atestada pela quantificação das atividades dos postos de profilaxia rural e dos serviços de proteção à infância e de inspeção escolar.

Embora os modos de uso das estatísticas sanitárias estivessem limitados pela montagem da coordenação nacional da política de saúde, os números forneceram a "medida comum" para a crítica das condições de higiene regionalmente desiguais do país. Como "tecnologia de tradução de interesses", as estatísticas tiveram um papel relevante na emancipação da saúde de sua antiga condição de ramo da administração estadual - como estabelecido pela Constituição de 1891 - e na sua promoção a uma esfera do social, ponto de ancoragem da demanda dos médicos por autonomia profissional e de crítica política das insuficiências da ordem oligárquica.

Longe de uma investigação exaustiva sobre as relações entre quantificação e saúde na Primeira República, a ambição foi realizar uma análise exploratória acerca das condições de difusão de uma razão estatística na gestão da população e dos fenômenos vitais. Para tanto, ampliou-se a escala de análise, com o fim de apreender dinâmicas somente perceptíveis na média e na longa duração. Essa opção se justificou pela relevância do objeto - as estatísticas sanitárias - e pela proposta de apresentá-lo como outro "ponto de vista" sobre a história da saúde, que permite lançar novos olhares sobre temas aqui tangenciados, como as representações das doenças, a organização da assistência, o movimento sanitarista e o desenvolvimento da profissão médica. Até recentemente empregada como meio de prova, cabe agora valorizar a quantificação como perspectiva de análise, reservando-lhe um lugar relevante na história e na historiografia das ciências. 


\section{NOTAS}

${ }^{1}$ Como exemplo desse tipo de argumento estatístico, podemos citar o estudo Apontamentos sobre a mortalidade da cidade do Rio de Janeiro, particularmente das crianças, publicado em 1878 pelo barão do Lavradio (1816-1892), presidente da Junta Central de Higiene. Visando avaliar a mortalidade no quinquênio 18681872, o autor utiliza dados coligidos de registros paroquiais e hospitalares para demonstrar a frequência significativamente maior da mortalidade infantil entre as crianças nascidas de união ilegítima, com a finalidade de construir um quadro alarmante, que solidificasse a urgência política do projeto higienista de remoção das habitações coletivas (Rego, 1878, p.28-29).

${ }^{2}$ Segundo Cukierman (2007, p.58), a fundação dos institutos teria que atender às seguintes traduções: “(1) que a peste, uma vez manifesta em Santos, se espalharia inexoravelmente pelo país, na sua pior forma, deixando atrás de si um rastro de pânico e morte; (2) que somente o soro vencia a peste (confirmavam-no a sanção do Instituto Pasteur ao soro de Yersin); (3) que um punhado de cientistas brasileiros estava apto a produzi-lo no país (esse punhado estivera reunido em Santos, trabalhando na identificação da moléstia e, ao mesmo tempo, exibindo sua capacitação técnica para combater o bacilo); (4) que não havia soro disponível para importação e que valia mais a pena investir em sua produção".

${ }^{3}$ Para Nancy Stepan (1976, p.167), a tríade formada pela fábrica, o laboratório e a escola constituiu a base do êxito da experiência de Manguinhos, sem equivalente na América Latina: "A história do Instituto Oswaldo Cruz mostrou que o sucesso na ciência dependeu de a instituição reunir, num único centro, pesquisa, aplicação, treinamento e atividade empresarial, devido à falta de organismos de apoio".

${ }^{4}$ Criada em 1897, a Diretoria-geral de Saúde Pública incorporou as funções do Instituto Sanitário Federal e da Inspetoria-geral de Saúde dos Portos. A instituição tinha, então, como atribuições a direção dos serviços sanitários dos portos marítimos e fluviais; a fiscalização do exercício da medicina e farmácia; estudos sobre doenças infectocontagiosas; a organização de estatísticas demográfico-sanitárias; e o auxílio aos estados, mediante solicitação dos respectivos governos, em situações especiais, como epidemias.

${ }^{5}$ Os problemas com a medicina clínica apareceram em diferentes ocasiões, como no relatório da DGSP, de 1905, especificamente na parte relativa à febre amarela, em que são relatadas as dificuldades derivadas da falha de diagnóstico e da subnotificação: "no correr do primeiro semestre deste ano, recebemos 137 notificações de casos de febre amarela. Desses casos, com excessivo rigor de observação, foram considerados positivos 95 e negativos 42. A demografia registrou rigorosamente como lhe cumpria, os 95 casos de febre amarela. Releva notar uma circunstância: esta Inspetoria registra e transmite à Seção Demográfica todos os casos em que os médicos mantêm o diagnóstico da febre amarela, 'qualquer que possa ser seu modo clínico de julgar o caso'. Alguns há que nos pareceram apenas suspeitos, outros que nos pareceram perfeitamente negativos" (relatório citado em Cuckierman, 2007, p.167; destaques meus).

${ }^{6}$ A cifra de $6 \%$ parece-nos bastante baixa para servir de referência à comparação proposta pelo organizador do censo, preocupado em mitigar o peso da participação estrangeira no setor de indústria e manufatura, que respondia por um número várias vezes maior de ocupados. Por outro lado, a mesma cifra se torna assombrosamente alta quando considerada a absorção estatal dos segmentos mais altos, diante da iniquidade do Estado para regular a ação e se fazer presente no território nacional.

${ }^{7} \mathrm{O}$ caso mais emblemático nesse sentido talvez seja o dos defensores do polimorfismo, como João Batista de Lacerda, que preconizavam a capacidade do parasito mudar de forma e função por influência do meio, especialmente dos fatores climáticos. Jaime Benchimol (2000, p.271) alerta que o polimorfismo legitimava o argumento de que doenças tropicais como a febre amarela e a varíola eram um campo de investigação acessível somente a cientistas das Américas, pois só aí, nesse meio particular, as doenças e seu agente manifestavam-se com características típicas.

\section{REFERÊNCIAS}

ALMEIDA, Marta; DANTES, Maria Amélia M. O serviço sanitário de São Paulo, a saúde pública e a microbiologia. In: Dantes, Maria Amélia M. (org.). Espaços de ciência no Brasil (1800-1930). Rio de Janeiro: Editora Fiocruz, 2001. p.135-155.

ALVES, Geraldo José. A contabilidade da higiene: representações da mortalidade no discurso médico- sanitário de São Paulo (1903-1915). Dissertação (Mestrado em História) - Universidade de São Paulo, São Paulo, 1999.

BENCHIMOL, Jaime Larry. A instituição da microbiologia e a história da saúde pública no Brasil. Ciência e Saúde Coletiva, v.5, n.2, p.265292, 2000. 
BENCHIMOL, Jaime Larry. Dos micróbios aos mosquitos: febre amarela e revolução pasteuriana no Brasil. Rio de Janeiro: Fiocruz; Editora da UFRJ, 1999.

BRASIL. Diretoria Geral de Estatística. Anuário estatístico do Brasil. 1908-1912, v.1. Rio de Janeiro: Tipografia da Estatística, 1916.

BRASIL. Relatório apresentado ao Presidente da República dos Estados Unidos do Brasil pelo ministro do Estado da Justiça e Negócios Interiores Wadislau Herculano de Freitas, em 1914. Rio de Janeiro: Imprensa Nacional, 1915.

BRASIL. Relatório apresentado ao Presidente da República dos Estados Unidos do Brasil pelo ministro do Estado da Justiça e Negócios Interiores Esmeraldino Olympio de Torres Bandeira, em 1910. Rio de Janeiro: Imprensa Nacional, 1910.

BRASIL. Diretoria Geral de Estatística. Recenseamento da cidade do Rio de Janeiro (Distrito Federal) realizado em 20 de setembro de 1906. Rio de Janeiro: Oficina de Estatística, 1907-1908.

BRASIL. Relatório apresentado ao Presidente da República dos Estados Unidos do Brasil pelo ministro do Estado da Justiça e Negócios Interiores Augusto Tavares de Lyra, em 1907. Rio de Janeiro: Imprensa Nacional, 1907.

BRASIL. Contribuição para o estudo epidemiológico da febre amarela pelo Dr. Bulhões Carvalho, médicodemografista. Rio de Janeiro: Imprensa Nacional, 1903.

BRASIL. Relatório apresentado ao Presidente da República dos Estados Unidos do Brasil pelo ministro do Estado da Justiça e Negócios Interiores Sabino Barroso, em 1901-1902. Rio de Janeiro: Imprensa Nacional, 1902.

BRASIL. Decreto n.1.647, de 12 de janeiro de 1894. In: Brasil. Coleção das Leis da República dos Estados Unidos do Brasil de 1894, v.1. Rio de Janeiro: Imprensa Nacional, 1895.

CABRAL, Dilma. Entre ideias e ações: lepra, medicina e políticas públicas de saúde no Brasil (1894-1934). Tese (Doutorado em História) Universidade Federal Fluminense, Niterói, 2007.

CAMARGO, Alexandre de Paiva Rio. O censo de 1872 e a utopia estatística do Brasil Imperial. História Unisinos, v.22, n.3, p.414-428, 2018.

CAMARGO, Alexandre de Paiva Rio. A construção da medida comum: estatística e política de população no Império e na Primeira República. Tese (Doutorado em Sociologia) - Universidade do Estado do Rio de Janeiro, Rio de Janeiro, 2016.

CAMARGO, Alexandre de Paiva Rio. Dimensões da nação: uma análise do discurso estatístico da Diretoria Geral de Estatística (1872-1930). Revista Brasileira de Ciências Sociais, v.30, n.87, p.79-97, 2015.

CAMARGO, Alexandre de Paiva Rio; DANIEL, Claudia. Os estudos sociais da quantificação e suas implicações na sociologia. Sociologias, v.23, n.56, p.42-81, 2021.

CARRARA, Sérgio. Tributo a Vênus: a luta contra a sífilis no Brasil, da passagem do século aos anos 40. Rio de Janeiro: Fiocruz, 1996.

CARVALHO, José Luiz Sayão de Bulhões. $O$ estado sanitário no Rio de Janeiro em 1906. Rio de Janeiro: Imprensa Nacional, 1907.

CUKIERMAN, Henrique. Yes, nós temos Pasteur: Manguinhos, Oswaldo Cruz e a história da ciência no Brasil. Rio de Janeiro: Relume Dumará; Faperj, 2007.

DESROSIÈRES, Alain. Pour une sociologie historique de la quantification: l'argument statistique I. Paris: Presses de l'École des Mines, 2008.

DIAZ-BONE, Rainer; DIDIER, Emmanuel. The sociology of quantification: perspectives on an emerging field in the social sciences. Historical Social Research, v.41, n.2, p.7-26, 2016.

FERREIRA, Luiz Otávio; FONSECA, Maria Rachel Fróes da; EDLER, Flávio Coelho. A Faculdade de Medicina do Rio de Janeiro no século XIX: a organização institucional e os modelos de ensino. In: Dantes, Maria Amélia M. (org.). Espaços de ciência no Brasil, 18001930. Rio de Janeiro: Editora Fiocruz, 2001. p.59-80.

FOUCAULT, Michel. O nascimento da biopolítica. São Paulo: Martins Fontes, 2009.

FOUCAULT, Michel. Segurança, território, população. São Paulo: Martins Fontes, 2008.

FRAGA, Clementino. Introdução ao Relatório dos Serviços do DNSP (1927) pelo Prof. Clementino Fraga. Rio de Janeiro: Inspetoria de Demografia Sanitária/Departamento Nacional de Saúde Pública, 1928.

HOCHMAN, Gilberto. A era do saneamento: as bases da política de saúde pública no Brasil. São Paulo: Hucitec, 2012.

HOCHMAN, Gilberto. Departamento Nacional de Saúde Pública. In: Abreu, Alzira Alves de et al. Dicionário histórico-biográfico brasileiro, pós-30. Rio de Janeiro: Editora FGV, 2001. CD-Rom.

KROPF, Simone. Doença de Chagas, doença do Brasil: ciência, saúde e nação, 1909-1962. Rio de Janeiro: Editora Fiocruz, 2009. 
LATOUR, Bruno. Ciência em ação: como seguir cientistas e engenheiros sociedade afora. São Paulo: Editora Unesp, 2000.

LATOUR, Bruno. The pasteurization of France. Cambridge: Harvard University Press, 1988.

LATOUR, Bruno. Give me a laboratory and I will raise the world. In: Knorr-Cetina, Karin; Mulkay, Michael. Science observed: perspectives on the social study of science. Newbury Park, CA: Sage, 1983. p.141-170.

LIMA, Nísia Trindade. Um sertão chamado Brasil: intelectuais e representação geográfica da identidade nacional. Rio de Janeiro: Iuperj; Revan, 1999.

O BRASIL MÉDICO, ano 37, v.2, p.372, 22 dez. 1923.

O BRASIL MÉDICO, ano 10, n.28, p.251, 22 jul. 1896.

O BRASIL MÉDICO, ano 10, n.7, p.62, 15 fev. 1896.

O BRASIL MÉDICO, ano 9, n.36, p.315, 29 set. 1895.

O BRASIL MÉDICO, ano 8, n.13, p.103, 1 abr. 1894.

OLIVEIRA, Lucia Lippi. A questão nacional na Primeira República. São Paulo: Brasiliense, 1990.

PORTER, Theodore. Trust in numbers: the pursuit of objectivity in science and public life. Princeton: Princeton University Press, 1995.
PORTER, Theodore. The rise of statistical thinking, 1820-1900. Princeton: Princeton University Press, 1986.

REGO, José Pereira, barão do Lavradio. Apontamentos sobre a mortalidade da cidade do Rio de Janeiro particularmente das crianças. Rio de Janeiro: Tipografia Nacional, 1878.

SANTOS, Luiz Antonio de Castro. O pensamento sanitarista na Primeira República: uma ideologia de construção da nacionalidade. Dados, v.28, n.2, p.193-209, 1985.

SCHWARCZ, Lilia Moritz. O espetáculo das raças: cientistas, instituições e questão racial no Brasil. São Paulo: Companhia das Letras, 1993.

SOUZA, Érica Mello de. Educação sanitária: orientações e práticas federais desde o Serviço de Propaganda e Educação Sanitária ao Serviço Nacional de Educação Sanitária, 1920-1940. Dissertação (Mestrado em História das Ciências e da Saúde) - Fundação Oswaldo Cruz, Rio de Janeiro, 2012.

STEPAN, Nancy. Gênese e evolução da ciência brasileira: Oswaldo Cruz e a política de investigação científica e médica. Rio de Janeiro: Arte Nova, 1976.

TELAROLLI JÚNIOR, Rodolpho. A secularização do registro de eventos vitais no estado de São Paulo. Revista Brasileira de Estudos de População, v.10, n.1-2, p.145-156, 1993.

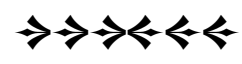

